\title{
Zo kan het ook: Een ander perspectief op organisatiewetenschap
}

Citation for published version (APA):

Roe, R. A. (2009). Zo kan het ook: Een ander perspectief op organisatiewetenschap: Afscheidsrede van Prof. Dr. Robert A. Roe. (1 ed.) Universiteit Maastricht. https://doi.org/10.26481/spe.20090423rr

Document status and date:

Published: 23/04/2009

DOI:

10.26481/spe.20090423rr

Document Version:

Publisher's PDF, also known as Version of record

\section{Please check the document version of this publication:}

- A submitted manuscript is the version of the article upon submission and before peer-review. There can be important differences between the submitted version and the official published version of record.

People interested in the research are advised to contact the author for the final version of the publication, or visit the DOI to the publisher's website.

- The final author version and the galley proof are versions of the publication after peer review.

- The final published version features the final layout of the paper including the volume, issue and page numbers.

Link to publication

\footnotetext{
General rights rights.

- You may freely distribute the URL identifying the publication in the public portal. please follow below link for the End User Agreement:

www.umlib.nl/taverne-license

Take down policy

If you believe that this document breaches copyright please contact us at:

repository@maastrichtuniversity.nl

providing details and we will investigate your claim.
}

Copyright and moral rights for the publications made accessible in the public portal are retained by the authors and/or other copyright owners and it is a condition of accessing publications that users recognise and abide by the legal requirements associated with these

- Users may download and print one copy of any publication from the public portal for the purpose of private study or research.

- You may not further distribute the material or use it for any profit-making activity or commercial gain

If the publication is distributed under the terms of Article $25 \mathrm{fa}$ of the Dutch Copyright Act, indicated by the "Taverne" license above, 
Zo kan het ook

Een ander perspectief op organisatiewetenschap 


\section{Colofon}

Ontwerp en print: Océ Business Services, Maastricht

ISBN: 978-90-5681-313-0

NUR: 774

Alle rechten voorbehouden. Niets uit deze uitgave mag worden verveelvoudigd, opgeslagen in een geautomatiseerd gegevensbestand of openbaar gemaakt worden, zonder voorafgaande schriftelijke toestemming van de auteur of uitgever. 


\section{Zo kan het ook}

\section{Een ander perspectief op organisatiewetenschap}

Maastricht, 23 april 2009

Prof.dr. Robert A. Roe 
Zo kan het ook. Een ander perspectief op organisatiewetenschap 
Meneer de Rector Magnificus

Collega's, studenten, familie, vrienden en bekenden

Geachte toehoorders

Het is zover. Sneller dan ik dacht is het moment gekomen waarop ik mijn academische carrière - althans in Nederland - afsluit met een openbare les. Het is verleidelijk om terug te kijken op de meer dan veertig jaar die achter mij liggen, mijn ervaringen op een rij te zetten, en te bekijken wat de oogst ervan is geweest. Ik zal er iets over zeggen maar vooral vooruitkijken. Per slot van rekening biedt de toekomst - ook in mijn vakgebied - meer uitdaging en inspiratie dan het verleden.

Dit college gaat over mensen en organisaties. Dat zal u niet verbazen. Wel misschien wat ik erover te zeggen heb, want ik wil het vooral hebben over zaken waar we weinig over weten en dan vooral omdat we er onvoldoende aandacht aan schenken. Ik wil pleiten voor een andere benadering in de studie van organisaties, om daarmee de cirkel waarin we ons bewegen te kunnen doorbreken. Het gezegde: "if you keep doing what you did, you keep getting what you got", geldt voor ons vakgebied ook. Als we nieuwe inzichten en resultaten willen, vraagt dat om een nieuwe benadering.

Ik wil vier thema's aan de orde stellen, namelijk: organisatie, tijd, mens en wereld. Hoewel elk van deze thema's een diepgaande behandeling zou verdienen, zal ik het kort houden en me beperken tot het aangeven van lacunes en manieren om die op te vullen. 


\section{Organisaties in mensen}

Binnen de organisatiewetenschap bestaan vele opvattingen over wat organisaties zijn. Een overheersende opvatting, door velen in de praktijk gedeeld, is dat de organisatie een afgebakende eenheid van mensen en middelen is. Dat blijkt bijvoorbeeld uit de volgende definitie: "de organisatie is een naar tijd en plaats geordend geheel van mensen en middelen, dat gericht is op de realisatie van een bepaald doel". In deze opvatting is de organisatie een entiteit die doelbewust gecreëerd en vorm gegeven is en die naar believen veranderd kan worden. Men kan ook zeggen dat de organisatie een "ding" is, dat dient als middel om een doel te bereiken. Mensen maken daar onderdeel van uit - we spreken over "mensen in de organisatie en bedoelen daarmee zowel medewerkers als degenen die hen "aansturen", de managers. Dat dit beeld van de organisatie ons vertrouwd voorkomt, mag gezien de historie ervan geen wonder heten. De kerkelijke, adellijke, militaire structuren uit vroeger eeuwen die via handel en industrie tot ons gekomen zijn, vormen er de oorsprong van. Waarschijnlijk is de populariteit van deze benadering echter te danken aan het zogeheten "wetenschappelijk management" dat in het begin van de zoste eeuw werd ontwikkeld (Taylor, 1911) en het middel organisatie tot een perfect instrument heeft trachten te maken.

De doorzichtigheid en maakbaarheid van organisaties die deze "formele" benadering suggereert, zijn aantrekkelijk. Immers, als de organisatie haar doel niet volledig bereikt of als men haar wil gebruiken om een ánder doel te bereiken, behoeft men haar maar te veranderen. Dat betekent uitbreiden of inkrimpen, aanpassen van de structuur, anders inrichten van processen. Het is de rol van de hoogsten in rang die via de hiërarchie opdrachten hiertoe verstrekken. Die hiërarchie wordt ook gebruikt om de organisatie te besturen. In wezen is dat ook een kwestie van opdrachten geven en controleren, of om het in militaire termen te zeggen "command and control".

Deze voorstelling van de organisatie is niet alleen onder wetenschappers maar ook onder "gewone mensen" erg populair. Zij wordt niet alleen op bedrijven toegepast, maar ook op bijvoorbeeld scholen, ziekenhuizen en gevangenissen. Door de eenzijdige belangstelling voor de formele kant van organisaties, schiet deze visie echter tekort waar het gedrag van mensen in het geding is en biedt zij een gebrekkige basis om organisaties te besturen. Zij is een voedingsbodem voor besturingsillusies, zoals bijvoorbeeld het idee dat de organisatie naar willekeur veranderd kan worden en onbeperkt kan groeien. Afgezien van het feit dat veranderingen vaak maar ten dele slagen, leidt een 
opeenvolging van ingrepen al gauw tot zgn. "veranderingsmoeheid". Groeien, door overnemen, samenvoegen, uitbreiden, kent op papier geen beperkingen en kan dus ook juridisch en boekhoudkundig eindeloos doorgaan. In werkelijkheid is dat niet zo en kunnen organisaties ook te groot worden, met als gevolg dat de samenhang achteruit gaat, niet langer effectief gepresteerd wordt, en de bestuurbaarheid verloren gaat. Grote, internationale bedrijven hebben zonder uitzondering moeite met de interne communicatie en samenwerking, en zijn onder crisisomstandigheden niet langer in staat adequat te functioneren, zoals de recente voorbeelden van ING en General Motors laten zien.

Het is niet moeilijk om ons een ander beeld van de organisatie te vormen. Als we van een afstand kijken naar wat mensen doen tijdens de 24 u ur van de dag en de 7 dagen van de week, zien we ze op bepaalde momenten naar een bepaalde plaats toegaan waar ze samenkomen met andere mensen en daar met hen bepaalde dingen doen. Aan sommige van die mensen gehoorzamen ze, aan anderen geven ze opdrachten; met sommigen werken ze samen, voor anderen doen ze iets - meestal iets nuttigs - en van weer anderen ontvangen ze een beloning. Ik heb het hier ook over de organisatie, maar nu als iets wat ontstaat in en door het samenspel van mensen, op bepaalde tijden. Zo bezien is de organisatie een tijdelijk en terugkerend fenomeen dat zichtbaar wordt op momenten dat mensen niet met andere dingen bezig zijn, zoals reizen, sporten, koken, kinderen naar bed brengen, enz. De organisatie komt op en gaat onder, elke dag opnieuw, gelijk de zon.

Wanneer we ons vizier nog iets verder openzetten en ons meer rekenschap geven van de factor tijd, verandert dat het beeld van de organisatie nog verder. We zien dan mensen op een bepaald moment in hun loopbaan zich bij een bepaalde gemeenschap van werkende mensen aansluiten en zich op een later tijdstip - al dan niet vrijwillig - weer afzonderen. Ik kom op dat begrip gemeenschap nog terug. Wie bij elkaar komen, wat ze gezamenlijk doen, wie naar wie luistert, wie samenwerkt of "zijn eigen ding doet", verandert over de tijd. Doordat mensen niet eeuwig blijven komen, maar vroeger of later afhaken, vaak om zich daarna voor een bepaalde periode bij anderen aan te sluiten, verandert datgene wat we "de organisatie" noemen. Over een nóg langer tijdvak bekeken, zien we nog iets anders: de organisatie ontstaat en verdwijnt op enig moment. Zoals het ooit begint met een handvol mensen die samen iets opstarten, eindigt het wanneer niemand van het gezelschap er nog iets in ziet, of wanneer iedereen met pensioen of overleden is. 
Als we het zo bekijken "bestaat" de organisatie niet echt, maar wordt ze "bedacht" door mensen - door ons, als toeschouwers die dit zien gebeuren, maar ook door de mensen die er bij betrokken zijn. Dat laatste leidt tot een omkering van begrippen: de mensen zitten niet in de organisatie, maar de organisatie zit in de mensen. Hoe vreemd dit misschien op het eerste gezicht ook lijkt, het heeft voordelen om het zo te benaderen. Het maakt allereerst duidelijk dat mensen tot meerdere organisaties kunnen behoren, iets wat slecht past binnen de formele denkwijze. Dat iemand een deel van de dag of een dag in de week met anderen doorbrengt en met hen weer andere dingen doet, is heel normaal en betekent inderdaad deel hebben aan verschillende organisaties. Interessant zijn de rolwisselingen die hierbij kunnen optreden: men speelt de rol van baas in het ene gezelschap, collega in het andere, of is klant in weer een andere. Ik heb hiermee iets gezegd, wat onder organisatiewetenschappers niet zo gebruikelijk is, namelijk dat we klanten ook tot de organisatie kunnen rekenen. Ik kom hier nog op terug.

Ten tweede, wanneer we de aandacht gericht houden op wat mensen doen in de uren van hun dag en de dagen van hun week, zien we dat maar een deel ervan met werk te maken heeft. Tijdbestedingstudies (bijv. Breedveld, 2001) bevestigen dat: ieder mens brengt een groot deel van de tijd door met mensen die niets met het werk te maken hebben - in het gezin, uitgaansleven, politiek e.d. Mensen hebben in het leven van alledag "wisselende contacten", die zich niet altijd rijmen laten met het idee uit de formele benadering, dat de organisaties een duidelijke grens heeft. Ontmoetingen met vrienden in het café, de voetbalkantine of de trein, met familieleden en buren bij verjaardagen en barbecues, met echtgenote/noot of vriend/in op de rand van het bed, of met oude klasgenoten, collega's en anonymi op Facebook, Myspace, Hyves of LinkedIn, kunnen er gemakkelijk toe leiden dat mensen informatie delen die eigenlijk binnen de "muren" van de organisatie zou moeten blijven. Ook kan het zijn dat ze elkaar diensten gaan leveren die formeel niet toelaatbaar zijn. Voorbeelden van loslippigheid, fraude en omkoperij zijn er in overvloed - ze vormen een vast bestanddeel van het dagelijkse nieuws. Dus: gedrag dat niet in de formele kijk op organisaties past, dat daarbinnen onlogisch of onbetamelijk is en zich moeilijk verklaren laat, is vanuit de alternatieve kijk op organisaties vrij voor de hand liggend. Het is duidelijk dat dit het idee van een grens tussen de organisatie en buitenwereld, en van grenzen tussen organisaties ondergraaft. De contacten tussen mensen die bij verschillende organisaties horen en 
dank zij hun werk regelmatig contact met elkaar hebben, leiden vaak tot duurzame netwerkrelaties die deze zogenaamde "grenzen" met gemak doorsnijden.

Ten derde, het omgekeerde organisatiebegrip is pas echt nuttig bij het begrijpen van organisatieverandering. Doelgericht veranderen van organisaties staat bekend as een lastige opgave, die veel tijd kost en vaak maar half slaagt (bijv. Lucey, 2008). Terwijl dit vanuit de formele kijk op organisaties moeilijk te verklaren is, is het vanuit de informele invalshoek bijna vanzelfsprekend. Het ontwerpen van een nieuwe organisatiestructuur, het op een rij zetten van voor- en nadelen, en het bekend stellen ervan "in de organisatie", is in veel gevallen niet erg moeilijk en kost weinig tijd. Maar om te bereiken dat mensen die gewoon zijn om dag-in dag-uit samen te werken en die aan het werk vriendschap, voldoening en status ontlenen, hun ideeën en hun gedrag gaan veranderen, moet er heel wat gebeuren. Onbegrip, onwil, weerstand zijn de gewoonste zaken in dit proces, evenals veel met elkaar praten, roddelen, beschuldigingen ventileren, bittere grappen maken. Dat mensen weggaan en een ander gezelschap zoeken, hoort er eveneens bij. Het kost allemaal veel tijd, veel meer dan men vanuit de formele organisatie zou verwachten.

Een bijkomstig voordeel van de informele benadering is dat zij tot een ander perspectief op arbeidsrelaties leidt, en in zekere zin bevrijdend werkt. De organisatie is immers te zien als "eigendom" van de mensen; het is aan hen te bepalen of ze er verder mee willen en hoe, maar ook of ze er vanaf willen. Dit gaat in tegen het gevestigde idee dat mensen "eigendom" zijn van de organisatie - de term is "human resources" waarover deze naar eigen goeddunken kan beschikken. Het ondermijnt de gedachte dat "strategen" bedrijven, zorginstellingen en scholen naar eigen inzicht kunnen samenvoegen, afsplitsen en verkopen, met inbegrip van medewerkers en klanten. Deze medewerkers en klanten zijn niet langer overgeleverd aan de macht van de organisatie, maar de organisatie blijkt hun speelbal te zijn en bewogen te worden door het geloof en de goodwill die zij eraan toekennen.

Klopt dit laatste wel? Is het wel realistisch om de soevereiniteit bij de medewerkers en klanten te leggen? Zij zijn, zoals het formele organisatiebegrip benadrukt, toch juist economisch en juridisch afhankelijk van de organisatie? Managers kunnen medewerkers toch dwingen om op tijd naar de aangegeven plaats te komen en de dingen te doen die overeengekomen zijn? Net zo goed als eigenaren de mogelijkheid hebben managers te dwingen dat te doen wat in het 
belang van de organisatie of in hun eigen belang is? Het antwoord op deze vragen is: ja, bij organisaties horen en er werk leveren is geen vrijblijvende aangelegenheid. Macht en dwang zijn inherent aan het maatschappelijke leven, ook waar het om organisaties gaat (Clegg, Courpasson, \& Phillips, 2006). Maar uiteindelijk is de keus om tot de ene of de andere organisatie te behoren en echt de inspanning te leveren die verwacht wordt, aan de mensen zelf. En daarmee berust de soevereiniteit bij hen, niet bij de organisatie (Y. Schwartz, 1992). Laat ik ter wille van een goed begrip maar een iets bredere formulering kiezen: het zijn niet alleen medewerkers en klanten van wie de organisatie afhankelijk is, maar ook andere belanghebbenden of "stakeholders"; daarmee is dan ook de rol van kapitaalverstrekkers duidelijk. Zolang er mensen zijn die willen werken en klanten die willen kopen, kunnen zij meespelen. Een hoofdrol is voor hen echter niet langer weggelegd.

Door de draai die ik er nu aan geef, doet deze visie op de informele organisatie misschien wat revolutionair aan. Toch is het idee dat organisaties geen "dingen" zijn waar mensen een onderdeel van zijn, maar een product van het menselijke denken en doen, niet nieuw. Er zijn tal van auteurs die van het formele denken over organisaties afstand hebben genomen. Vooral Weick $(1979,1995)$ heeft de nadruk gelegd op het aanhoudende proces van organiseren dat in de interactie van mensen besloten ligt en de organisatie telkens een nieuwe vorm geeft. Giddens (1984) benadrukt in zijn bekende "structuratietheorie" de wisselwerking tussen structuur en handelen, wat verwijst naar de verbinding tussen de informele en de formele organisatie, een relatie als tussen ei en kip. In het begrip informele organisatie zit ook het algemene idee dat wat mensen denken bepalend is voor wat tot stand komt, bekend als "sociaal constructionisme". Dit is een inzicht dat sinds de jaren 70-80 in brede kring geaccepteerd wordt. Hiernaast is er een uitgebreide literatuur over "organisatiegedrag" die een sterke nadruk legt op de manier waarop mensen zaken waarnemen en interpreteren, en de gevolgen die dat heeft voor hun gedrag (bijv. Cooper \& Clegg, 2008).

Is er dan wel iets nieuws in wat ik beweer? Ik denk van wel. Ik leg het accent op het feit dat organisaties tijdelijke en veranderlijke bedenksels zijn die, hoewel er ook een sturend effect van uitgaat, het feitelijke doen en laten van groepen mensen weerspiegelen en tot op zekere hoogte ook door hen gecontroleerd kunnen worden. Juist in de crisis van het marktkapitalisme die we nu doormaken, valt dat laatste te herkennen. Tegenover de organisaties die medewerkers aan de kant zetten en klanten "afstoten"of "opkopen", zijn er - zie het voorbeeld van ABN-AMRO - 
medewerkers en klanten die weigeren "afgedankt" of "overgenomen" te worden en zelf overstappen naar een andere organisatie. Meer dan medewerkers, die door hun gebondenheid aan plaats en inkomen een grotere traagheid hebben, hebben klanten de macht om organisaties te maken en te breken. Wanneer zij massaal besluiten over te stappen naareen andere leverancier, bepalen zij daarmee of organisaties groeien, krimpen en nog recht van bestaan hebben. We hebben gezien dat Amerikaanse huizenbezitters door hun rekeningen niet langer te betalen imposante bedrijven kunnen laten "omvallen" en het hele kapitaalsysteem onderuit kunnen halen. Het is interessant te constateren dat de schaalvergroting en toenemende concurrentie die met groei van het wereldkapitalisme gepaard zijn gegaan weliswaar tot doel hadden om grotere en krachtiger bedrijven te creëren, maar in feite meer macht bij de consumenten hebben gelegd - zeker in een tijd waarin de markt steeds meer via Internet gestalte krijgt.

Met betrekking tot de informele organisatie is gelukkig al veel onderzoek gedaan, bijvoorbeeld rond thema's als arbeidstevredenheid, teams, leiderschap, conflicten, vertrouwen en dergelijke, en dat heeft het belang van de menselijke factor overtuigend aangetoond (Robbins, 2007). Toch volgt het onderzoek vaak het denkkader van de formele organisatie. Het gaat bijna altijd om "mensen binnen organisaties", aangesteld als employee en blootgesteld aan bepaalde managementpraktijken, die onderzocht worden. Bijna nergens wordt de vraag gesteld hoe deze inkadering de opzet en het resultaat van het onderzoek beïnvloedt. Mij dunkt dat wij als onderzoekers meer afstand zouden kunnen nemen van dit model en de denkrichting zouden kunnen omkeren zodat het gedrag en dus de informele organisatie voorop komt te staan en de formele organisatie als uitkomst wordt gezien. In onderzoeksjargon: een omkering van onafhankelijke en afhankelijke variabele. Dat kan tot nieuwe vragen leiden, zoals: "Welke invloed heeft gedrag van medewerkers - bijvoorbeeld strategisch veranderen van werkgever - op de organisatiestructuur?" Ik ben ervan overtuigd dat dit tot nieuwe ontdekkingen kan leiden en daardoor een beter begrip van de relatie tussen de informele en de formele organisatie kan geven. Hoewel er managers zijn die goed met de informele organisatie weten om te gaan - Egan heeft er een interessant boek over geschreven met de titel "Working the shadow side" (Egan, 1994) - zullen inzichten die uit onderzoek naar voren komen ook voor veel managers (en medewerkers) nuttig kunnen zijn. Het kan helpen om tussen formele en informele organisatie een realistische balans te vinden. 
In mijn eigen onderzoekgroep - vergeef me dat ik het zo uitdruk hebben we de laatste jaren geprobeerd een aantal facetten van de informele organisatie te belichten. In een promotieonderzoek van Fons Naus is aangetoond dat medewerkers vaak anders over hun organisatie denken dan managers geneigd zijn aan te nemen, waarbij met name cynisme veel voorkomt (Naus, 2007). Ad van Iterson maakt studie van een ander intermenselijk fenomeen, namelijk roddelen (Soeters \& Van Iterson, 2002; Van Iterson \& Clegg, 2008). Peter Berends probeert uit te vinden hoe het komt dat mensen zich als manager anders gedragen dan ze tevoren zeggen dat ze zich zullen gedragen - een curieuze tegenstelling. Dat er een verschil is tussen hoe mensen zijn en wat ze aan anderen laten zien, bekend als "impressie-management", is uitvoerig onderzocht door Sara Safay die binnenkort haar proefschrift hierover verdedigt. We hebben ook het functioneren van managers onderzocht, waarbij - met name in de dissertatie van Anneloes Raes - gekeken is naar de manier waarop zij in teamverband met elkaar omgaan (Raes, 2008). Ander onderzoek heeft zich gericht op sociale netwerken binnen en tussen organisaties en de rol van vertrouwen (Blumberg, Peiró, \& Roe). Ik denk dat de netwerkbenadering bij uitstek geschikt is om de informele organisatie te bestuderen.

Samenvattend: Organisaties kunnen niet zonder formele structuur, maar ze kunnen daaraan niet gelijkgesteld worden. Ze zijn ook te zien als product van menselijk denken en doen. Het is geen nieuw idee. We weten het, maar toch blijven we praten over "mensen in de organisatie". We behandelen mensen als "resources", die tot het kapitaal van de organisatie behoren, die aangetrokken, gevormd en onderhouden moeten worden, bij wie betrokkenheid moet worden gekweekt, van wie de weerstand moet worden weggenomen - als waren zij onderdelen van een stroef lopende machine. Dat leidt tot een verwrongen beeld en tegenstrijdige acties. Het is tijd om organisaties anders te bekijken en te spreken over "mensen bij de organisatie" of "mensen als partners". Dat leidt tot een ander perspectief, meer realistisch en meer menselijk. Het zet een andere toon en legt de basis voor andere relaties, die de omgang met elkaar en de dienstverlening aan anderen alleen maar ten goede kan komen. Dát het kan, wordt in de praktijk bewezen door bedrijven die als goede werkgever bekend staan. Nu moeten de onderzoekers er nog van doordrongen worden. 


\section{Dynamiek}

Dank zij de respectabele geschiedenis van de organisatiewetenschap weten we inmiddels veel over hoe organisaties opgezet en veranderd kunnen worden en over hoe ze functioneren. Althans, er is veel onderzoek naar gedaan en dat doet ons geloven dat we er veel over weten. Echter, als we het van dichtbij bekijken, wacht ons een teleurstelling. Het blijkt namelijk dat er verrassend weinig onderzoek gedaan is naar wat in organisaties wérkelijk gebeurt. Ik heb het dan over doen en laten van mensen, de manier waarop zij met elkaar omgaan, veranderingen in de cultuur en de structuur zoals die zich in de tijd voltrekken, en over de manier waarop deze in de prestaties van organisaties doorwerken. Hoewel belang van de factor tijd evident is, is onze kennis erover uiterst beperkt. We weten verduveld weinig over de duur van gedragsprocessen, het verloop ervan, stagnaties en versnellingen, enz. Deze leemte in onze kennis is een gevolgvan de manierwaaropwijorganisatiewetenschappers onderzoek plegen te doen. We zijn goed in het bekijken van verschillen tussen mensen, teams, structuren, omgevingscondities en in het maken van vergelijkingen, het bepalen van statistische verbanden en het trekken van conclusies daaruit. Maar we hebben moeite met processen, d.w.z. patronen die zich over dagen, weken, kwartalen uitstrekken. Een goed voorbeeld is cultuur: we zijn goed in het benoemen van verschillen (denk aan de cultuurdimensies van Hofstede, 1980) maar blind voor verandering. Wanneer we in verband met organisaties over nationale culturen spreken, blijven we verschillen uit de jaren 70 en 80 benoemen, in plaats van te onderzoeken hoe uit oude en nieuwe elementen andere culturele patronen zijn ontstaan.

Merkwaardig is ook het contrast tussen de verwaarlozing van tijd in onze kennis en het allesbeheersende belang ervan in organisaties. De organisatietheorie doet er het zwijgen toe, terwijl alle betrokken partijen, d.w.z. klanten, leveranciers, vervoerders, medewerkers en managers, geïnteresseerd zijn in de vraag wanneer dingen gebeuren, hoe lang ze duren, of er vertraging optreedt, wanneer een reactie te verwachten is, enz. De tegenstelling is vooral opmerkelijk bij de studie van organisatieverandering, wat per definitie een dynamisch proces is en eenvoudigweg om een temporele benadering vraagt.

Verscheidene auteurs, mijzelf inbegrepen, hebben in de afgelopen jaren gewezen op het onbevredigende van deze situatie (George \& Jones, 2000; Mitchell \& James, 2001; Roe, 2008). Er is te weinig bekend over het verloop van processen en hun relaties, en wat we ervan weten is vertekend omdat het berust op interpretaties van vergelijkend onderzoek. 
Hoewel het vaak gedacht wordt, laten de conclusies van vergelijkend (differentieel) onderzoekzich niet omzetten naarvolgtijdelijk (temporeel) onderzoek. De samenhang tussen A en B binnen een groep mensen op een bepaald moment in de tijd zegt niets over de relatie tussen A en $B$ bij dezelfde persoon, of dezelfde personen, over de tijd. Bijvoorbeeld: als blijkt dat in een groep mensen de mate van beloning samenhangt met de mate van tevredenheid, wil dat niet zeggen dat bij een willekeurig persoon het ontvangen van een hogere beloning gepaard gaat met meer tevredenheid. Als gevonden wordt dat diversiteit in teams geassocieerd is met hogere productiviteit, wil dat niet zeggen dat het vergroten van de diversiteit - door het vervangen van een teamlid binnen bestaande teams tot meer productiviteit leidt. Wie denkt dat dit wel zo is, vergist zich. Om dat te onderstrepen nog een voorbeeld uit een ander vakgebied. Als in een studie gevonden is dat mannen die in hun leven veel tomaten hebben gegeten in doorsnee een kleinere prostaat hebben dan mannen die weinig tomaten hebben gegeten, wil dat niet zeggen dat mannen die (vanaf een bepaald moment) meer tomaten gaan eten, de prostaat minder groot wordt of niet meer groeit. De twee typen onderzoek - differentieel en temporeel - zijn niet verwisselbaar omdat ze op een andere doorsnede van de werkelijkheid betrekking hebben.

Natuurlijk is niet alle organisatieonderzoek vergelijkend van aard. Er wordt ook longitudinaal onderzoek gedaan met meerdere momenten van observatie, maar de omvang ervan blijft bescheiden. Ook blijft, anders dan men zou verwachten, de factor tijd vaak onderbelicht omdat onderzoekers meer geïnteresseerd zijn in de volgorde waarin dingen gebeuren (A komt vóór B, of omgekeerd) en daarmee causale relaties menen te kunnen demonstreren. In de literatuur zijn ook veel experimenten en casestudies beschreven, waarin veranderingen in de tijd onderzocht zijn. Deze studies hebben echter weer andere beperkingen. Afgezien van het feit dat zij plaatsvinden onder zeer restrictieve condities, waardoor ze moeilijk te generaliseren zijn en in een groter kennisbestand te passen, zijn in de meeste gevallen de tijdsaspecten onvoldoende gedocumenteerd om over processen veel te kunnen leren.

We kunnen ook een andere aanpak volgen en het onderzoek zo inrichten dat duidelijk wordt hoe fenomenen zich in de tijd ontwikkelen en samenhangen. Daar hebben meerdere collega's voor gepleit (Ancona, Okhuysen, \& Perlow, 2001; Van de Ven, 2007). Ik heb me zelf ook op dit terrein begeven en in een aantal recente publicaties en congresbijdragen 
aangegeven wat soort vraagstellingen in dit onderzoek leidend kunnen zijn en hoe het kan worden opgezet en uitgevoerd (bijv. Roe, 2005, 2008, 2009). Mijn suggestie is om, voorafgaand aan het onderzoek, de kernbegrippen tegen het licht te houden omdat die, vreemd genoeg, temporeel onderzoek kunnen bemoeilijken. Als het mogelijk is om werkwoorden te gebruiken in plaats van de gebruikelijke zelfstandige naamwoorden-bijvoorbeeld:communiceren in plaats van communicatie, of leidinggeven in plaats van leiderschap - helpt dat al om processen en veranderingen te zien. Ook helpt het om naar de levenscyclus van de te onderzoeken fenomenen te kijken. Niets aan mensen of organisaties is eeuwig - alles wat er aan hen te zien is, is tijdelijk, d.w.z. heeft een begin, een duur en een einde. De bril van de levenscyclus geeft een ander kijk op de werkelijkheid van mensen en organisaties, veel rijker aan informatie over hoe het er werkelijk aan toe gaat en waarom dat zo is.

Deliteratuurheeft verschillendesuggestiesopgeleverdvoortemporeel onderzoek (bijv. Bluedorn, 2002; McGrath \& Tschan, 2004; Roe, Waller, \& Clegg, 2009). Het gebruik van longitudinale onderzoeksdesigns, waarin een of meer variabelen meerdere keren bij dezelfde personen of groepen gemeten worden, ligt voor de hand. Evenals het gebruik van speciale analysemethoden, zoals time series analysis, event history analysis, latent growth modeling, enz. Er is een groeiende methodologische literatuur die aangeeft hoe men studies moet opzetten en hoe men tijdreeksen kan verzamelen en analyseren (bijv. Lynn, 2009; Van de Ven, 2007). Er zijn ook allerlei publicaties over specifieke methoden waarmee, op een niet-te-opvallende manier, gegevens verzameld kunnen worden, zoals bijvoorbeeld met dagboeken, elektronische middelen, of videoregistraties.

Toepassingen van zulke methoden zijn er ook, maar ze zijn vrij schaars. Een voorbeeld is ouder onderzoek van Gersick (1989) over zgn. "pointed-equilibrium model", waaruit blijkt dat projectgroepen die met een deadline werken, halverwege de tijd een omslagpunt meemaken, waarin ze anders gaan werken. Een ander voorbeeld is een studie van Beintein en anderen (2005) waarin een "latent groeimodel" is gebruikt om veranderingen in betrokkenheid van medewerkers te beschrijven. Over het geheel wil het nog niet erg vlotten met temporeel onderzoek op ons vakgebied en dat heeft behalve met praktische problemen (het vraagt om meer tijd en inspanning) ook te maken met een onvermogen om in termen van processen te denken. We weten wel dat dingen veranderen, maar vallen telkens weer terug in de gewoonte om naar verschillen te kijken. 
Om aan dit probleem te ontkomen, heb ik voorgesteld om in het onderzoek drie stappen te zetten (Roe, 2008). De eerste stap is het beschrijven van het fenomeen, bijvoorbeeld leiding geven of samenwerken in een team, in temporele termen. Hier komt het begrip "levenscyclus" van pas. Het leidt tot vragen als: Wanneer begint het en wat gebeurt er dan? Wanneer eindigt het en wat gebeurt er dan? Wat gebeurt er in de tussentijd? Zijn er fasen? Wat voor ontwikkelingen zijn er te zien binnen de stadia van de levensloop? Deze vragen dwingen ons om de aandacht te richten op wat er gebeurt en op aspecten als "timing", duur, vermindering en groei waarin het verloop in de tijd tot uitdrukking komt.

De tweede stap is het onderzoeken van de relatie tussen twee (of meer) fenomenen. Wanneer leidinggeven door (een manager) en samenwerken (binnen een team) gezien worden als processen die zich in de tijd voltrekken, wordt het mogelijk om de dynamische relaties tussen beide gedetailleerd in kaart te brengen. Hierbij komen allerlei vragen naar voren. Bijvoorbeeld: hoe hangen de eerste dingen die de leider doet, wanneer deze nét in functie is, samen met wat het team vervolgens doet? Worden acties van de leider wel gevolgd door veranderingen in het gedrag van het team? Hoe lang duurt het voordat zo'n effect zichtbaar wordt? Heeft een wisselvallige manier van leidinggeven een andere uitwerking dan een stabiele? Wordt de invloed van de leider op den duur zwakker of juist sterker? Omdat er aan de beide fenomenen vele dynamische aspecten te onderscheiden zijn (duur, stijging, daling, stabiliteit, variatie, ritmiek etc.) zijn er ook aan de relatie tussen hen vele aspecten te onderscheiden. $U$ merkt wel, het leidt tot vele vragen, die niet alleen interessant zijn voor de wetenschap, maar ook voor een praktijk die wil weten hoe lang iets duurt, wanneer ingegrepen moet worden, wanneer een effect te verwachten is e.d. Het zijn precies de vragen waarop we nu geen antwoord hebben.

De derde stap betreft een andere kijk op de tijdsdimensie in het groot. Nu gaat het om de vraag hoe de patronen die in onderzoek gevonden in de loop van de tijd stand houden, dus om de geldigheid van onze kennis op langere termijn. Anders gezegd, hoe zit het met de uiterste houdbaarheidsdatum van onze kennis? Zijn er lange termijn trends? Zijn er misschien plotselinge veranderingen als gevolg van belangrijke maatschappelijke gebeurtenissen? Het kan heel goed zijn dat een oorlog, een ramp zoals "9-11" of de orkaan Katrina, of de huidige financiële crisis tot wezenlijke veranderingen in organisaties leiden. Ook relatief langzame veranderingen, zoals de ontwikkeling van de 
informatie- en communicatie-technologie, kunnen een effect hebben. De manier waarop nu gecommuniceerd wordt en besluiten genomen worden zou zonder Internet bijvoorbeeld ondenkbaar zijn geweest.

In de organisatiewetenschap bestaat voor deze vragen nog weinig interesse. Het is alsof we ervan uitgaan dat eenmaal gepubliceerde kennis onbeperkt geldig blijft. Het duidelijkst blijkt dat in zgn. "meta-analytisch onderzoek", waarin onderzoeksresultaten uit vele verschillende studies op een hoop geveegd worden en conclusies getrokken worden over "algemene samenhangen", zonder dat rekening gehouden wordt met het tijdstip warop het onderzoek werd verricht. Dit soort onderzoek is aanvechtbaar en zou plaats moeten maken voor onderzoek naar historische bepaaldheid en generaliseerbaarheid. Eigenlijk zou de organisatiewetenschap - net als de sociale wetenschappen in het algemeen - moeten breken met de aanname dat alles bij het oude blijft tot het tegendeel blijkt en er vanuit moeten gaan dat alles verandert tot het tegendeel blijkt.

Dat zich een nieuw perspectief ontvouwt wanneer we de tijd op deze manier in het onderzoek betrekken, wil ik graag duidelijk maken aan de hand enkele studies die recent in mijn omgeving verricht zijn. Deze studies zijn allemaal gebaseerd op herhaalde metingen van eenzelfde fenomeen, zij het dat het object van studie en de vraagstelling verschilt. Het beginpunt was onderzoek door Josette Gevers aan de TU Eindhoven, waar ik als mede-promotor bij betrokken was (Gevers, 2004). Het onderzoek had betrekking op de vraag of de prestaties van projectteams afhangen van de mate waarin leden van die groepen een gelijk beeld hebben van de uit te voeren taken, de tijdsbesteding daarbij en de taakverdeling binnen het team (zgn. "shared mental models"). In sommige teams bleek de overeenstemming groter te worden en in andere juist kleiner, waarbij dat verschil leidde tot betere resp. slechtere prestaties. Uit een analyse van andere groepsstudies bleek dat dit patroon, waarbij verschillen met de tijd groter worden, vaker voorkomt (Waller, Roe, Gevers, \& Raes, 2005). We gaven het de naam "vork" (Engels: bifurcatie) en gingen op zoek naar meer voorbeelden. In een onderzoek door Anneloes Raes werd gevonden dat managementteams die over een periode van 10 maanden gevolgd werden ook een vork-verschijnsel lieten zien, ditmaal in vertrouwen en conflict (Raes, Heijltjes, \& Glunk, 2009). In sommige teams daalde het niveau van vertrouwen van de leden in elkaar en groeide de mate van persoonlijk conflict, terwijl andere teams min of meer stabiel bleven. Er werd eveneens een relatie met prestaties gevonden. 
Ander onderzoek kijkt naar de betrokkenheid van medewerkers ten opzichte van de organisatie waarvoor zij werken. Het onderzoek wordt uitgevoerd door Omar Solinger en wordt dit jaar afgerond met een dissertatie. Met een speciale meetmethode is wekelijks de betrokkenheid van individuen gemeten over een periode van ca een half jaar. Uit een analyse van de gegevens blijkt dat er verschillende dynamische patronen zijn - dalend, stijgend met en zonder schokken; meer zal ik niet verklappen - die duidelijk van elkaar verschillen. Ik wil hier ook melding maken van een proef door student Stefan Selders waarin met een verwante methode de betrokkenheid van medewerkers maar liefst twee maal per dag werd gemeten over een tijdvak van vier weken. Deze studies bevatten uiterst interessante waarnemingen die de vergelijkende studies uit het verleden op losse schroeven zetten. Hetzelfde geldt voor nog lopend promotieonderzoek door Jia Li naar de stabiliteit van temporele stijlen, waaronder oriëntatie op heden, verleden en toekomst, bij individuen en groepen over een periode van meerdere maanden. Ook hier treden verschillende ontwikkelingspatronen aan het licht die met prestaties samenhangen. Haar dissertatie is eveneens dit jaar te verwachten.

De studies die ik hier noem, betreffen slechts een klein aantal gedragsfenomenen. Maar zij demonstreren dat dynamische patronen significante verschillen kunnen vertonen en bovendien dat zulke verschillen invloed kunnen hebben op andere fenomenen, zoals het leveren van prestaties. Dat dynamische patronen ook aan oorzaken gerelateerd kunnen heb ik in een heel andere context kunnen constateren - daar ging het om de stijging, daling en stabiliteit van autoritarisme bij werkende mensen in reactie op socio-economische omstandigheden in het Bulgarije van de jaren 90 (Roe, 2007). Verder onderzoek op dit gebied, waarbij oorzaken en gevolgen zelf ook dynamisch onderzocht worden, is voor de praktijk erg belangrijk. Het kan leiden tot antwoord op vragen waarop we tot nu toe het antwoord schuldig moesten blijven. Hoe komt het, bijvoorbeeld, dat groepen die onder normale omstandigheden op dezelfde manier presteren zich onder crisisomstandigheden splitsen in groepen die beter en andere die slechter gaan functioneren (Waller, Roe, Gevers, \& Raes, 2005)? Het is een van de vele vragen in het onderzoek naar bifurcatie. Hoe komt het dat bij het aanleren van taken sommige mensen in staat zijn om vorderingen te maken en anderen niet? Het laatste komt aan de orde in de recente dissertatie van door Esther Oprins over de training van luchtverkeersleiders (Oprins, 2008). 
Over onderzoek naar de geldigheid van onderzoeksresultaten over de tijd heb ik nog niet veel te melden. Hier zijn dataverzameling en analyse nog gaande. Als het onderzoek de kant uitgaat die ik zou willen, komt er een moment waarop elke onderzoekspublicatie voorzien wordt van een uiterste houdbaarheidsdatum.

Ik moet erop wijzen dat de benadering die ik heb voorgesteld en toegelicht uitgaat van een objectieve, chronometrische kijk op de tijd. Hoe belangrijk ook, het is slechts een kant van de medaille. Mensen zijn zich bewust van de tijd, denken erover na en stemmen hun handelen erop af. Het maakt bijvoorbeeld verschil of iemand vindt dat de tijd langzaam loopt, wat een gevoel van verveling oproept, of dat de tijd snel gaat, wat met gevoel van haast gepaard gaat. Een ander voorbeeld is "time discounting": wat verder weg ligt in de tijd legt bij beslissingen minder gewicht in de schaal dan wat dichterbij is. De bestudering van tijdsperceptie en -beleving is interessant, omdat zij van invloed kunnen zijn op de manier waarop individuen werken en op de samenwerking binnen teams (o.a.McGrath \& Tschan, 2004; Waller, Conte, Gibson, \& Carpenter, 2001).

De relatie tussen de tijdbeleving en het handelen van het individu staat centraal in "time management", een gebied waaraan wij de laatste jaren ook aandacht hebben besteed (o.a. Claessens, Van Eerde, Rutte, \& Roe, 2004, 2007). Door Brigitte Claessens is er aan de TU Eindhoven een interessant proefschrift over geschreven, waarikeveneens medepromotor was (Claessens, 2004). Het is in grote lijnen bekend hoe time management werkt en wat het effect ervan is, maar er zijn ook nog open vragen. Een daarvan is opgepakt in een promotieonderzoek van Daniela Kirchberg: "Hoe gaan mensen om met meerdere werkdoelen, wanneer er, terwijl ze bezig met het afwerken van bepaalde doelen, er andere doelen bijkomen?" Ten aanzien van dit "multiple goal management" zijn met behulp van dagboekmethoden (PDA) zeer interessante observaties verzameld over manieren van doelmanagement en hun effectiviteit gedaan; er zal binnenkort over een conferentie verslag van worden gedaan (Kirchberg \& Roe, 2009).

Over tijd in relatie tot het gedrag van groepen is onderzoek gedaan door Mary Waller, die enkele jaren in ons team heeft gewerkt. Zij is sterk geïnteresseerd in het functioneren van teams in crisissituaties, vooral omdat ze maar beperkte tijd voor handelen hebben (Waller, Roe, Gevers, Raes, \& Kaplan, 2007). Samen met promovendus Sjir Uitdewillegen heeft zij op grond van de mondelinge gesprekken die in het commandocentrum van NEADS (Northeast Air Defense Sector) 
zijn opgenomen tijdens de "9-11" aanval een analyse gemaakt van de zich ontwikkelende beeldvorming gedurende de aanval (Waller \& Uitdewilligen, 2009). Sjir houdt zich onderwijl bezig met de bestudering van gedrag bij leden van "control teams" in de luchtvaart, de scheepvaart en bij het spoor. Voor hem is de vraag hoe gedeelde mentale modellen ("shared mental models") waarvan de tijd een belangrijk onderdeel is, het handelen beïnvloeden. Onderzoeker Hannes Guenter tenslotte, gaat een stap verder en stelt dat tijdsperceptie en -beleving niet alleen binnen groepen van belang is, maar doorwerkt in de relaties tussen groepen en zelfs tussen organisaties. Dit vormt het uitgangspunt van een nieuwe studie in onze groep naar het effect van feitelijke en waargenomen vertragingen op de samenwerking van mensen in business-to-business relaties.

Samenvattend: Ons leven is doortrokken van de tijd, maar we zien de wereld als een stilleven. Het denken in termen van vaste eenheden en onze neiging om te leren van vergelijking, bemoeilijkt ons begrip van de dynamiek van de werkelijkheid en ons vermogen om er goed in te handelen. Dat we het ook anders kunnen zien, is geen nieuw inzicht - de oude Grieken hadden het er al over - maar we hebben verzuimd er consequenties uit te trekken. Wat ik bepleit is een andere vorm van wetenschap over organisaties, waarin alles in de eerste plaats temporeel wordt bekeken en pas in de tweede plaats differentieel. Ik verwacht dat dit veel nieuwe kennis zal opleveren en ons vermogen om te handelen enorm zal uitbreiden.

\section{De collectieve mens}

We kunnen niet over organisaties spreken zonder het over mensen te hebben. Het bleek al uit de definitie; organisaties zonder mensen bestaan niet. Waar ik het nu over wil hebben, is de manier waarop we bij de studie van organisaties over mensen denken - dat lijkt geen luxe als we willen proberen mensen te begrijpen en te beïnvloeden. Vreemd genoeg vallen definities van de mens in de organisatieliteratuur op door afwezigheid. Wetenschappers nemen wel de moeite om begrippen als organisatie, team, manager e.d. te definiëren, maar voor het begrip mens is dat kennelijk niet nodig. Waarom niet? Spreekt het vanzelf wat we bedoelen als we over mensen spreken? Mogen we een uniform mensbeeld veronderstellen dat onder alle condities op iedereen van toepassing is?

Als we naar de betekenis van het begrip mens op zoek gaan, komen we tot de constatering dat het usance is de mens als individu (letterlijk: 
een ondeelbare) aan te duiden. Mensen en individuen zijn de facto synonieme begrippen. De gangbare gedachte is dat ieder individu zich een beeld vormt van de situatie waarin hij/zij zich bevindt, nadenkt over mogelijke handelingen, keuzes maakt en daarnaar handelt. Het beeld van het individu dat zelfstandig keuzes maakt en daarmee verantwoordelijk is voor het eigen gedrag, wordt niet alleen in de organisatiewetenschap maar ook in de samenleving algemeen geaccepteerd. We zien het ook terug in het begrip "burger" uit de moderne politieke theorie. Er wordt uitgegaan van een homogene verzameling burgers, die onderling aan elkaar gelijk zijn, en elk een autonome eenheid in het staatsbestel vormen. Dat is interessant, omdat in de vakliteratuur ook over mensen als "burgers in de organisatie" ("organizational citizenship", Schnake, 1991) wordt gesproken.

Hoewel we hier allen mee vertrouwd zijn, is de gelijkschakeling van mens en individu om een aantal redenen niet vanzelfsprekend. Allereerst omdat iedereen als lid van een gemeenschap en meestal ook van een gezin ter wereld komt, in een dóór-en-dóór sociale omgeving opgroeit en vanaf de eerste dag leert om anderen na te doen, na te zeggen, en te behagen. Individueel gedrag is iets was geleerd moet worden, als het ware uit de sociale ruimte uitgehouwen moet worden, maar zo dat daarvan voldoende overblijft. Wie daarbij te ver gaat, gedraagt zich niet individueel maar a-sociaal. Ten tweede omdat het individu dat naar eigen goeddunken handelt een figuur van recente datum is. Individualisme is verbonden met de moderne tijd. De acceptatie van de mens als individu was tot minder dan een eeuw geleden voorbehouden aan vorsten en aan welgestelde burgers, wetenschappers inbegrepen. Pas in de tijd van de Verlichting, wanneer filosofen voldoende welstand bereiken om zich aan het sociale leven te ontrekken - ik denk aan personages als Descartes en Goethe - begint zich het beeld van de mens als weldenkende en rationeel handelende eenling te verbreiden. Ten derde, omdat menselijk gedrag in feite overwegend collectief is. Wat de een zegt en doet, hangt sterk samen met wat anderen zeggen en doen. We zijn weliswaar niet gewoon het zo te zien, maar veel van ons dagelijkse handelen komt overeen met het handelen van anderen. We staan op, lezen de krant, gaan in de trein of met de auto naar ons werk, verrichten taken, gaan weer naar huis, gaan aan tafel, doen de afwas, kijken TV enz. Over veel zaken zeggen en denken we hetzelfde, wat geen wonder is gezien onze beïnvloeding door onderwijs, massamedia en onderlinge communicatie. Een flinke portie van ons gedrag is ook bepaald door de rollen die we binnen de samenleving en binnen 
organisaties vervullen: we doen wat we geacht worden te doen, gegeven de positie die we innemen.

Hoewel mensen natuurlijk ook als individu handelen, d.w.z. persoonlijke keuzes maken en zich "eigenwijs" gedragen, is de opvatting van de mens als individu voor de organisatiewetenschap beslist ontoereikend. Zij spoort niet voldoende met wat we waarnemen en geeft een vertekend beeld waaruit gemakkelijk misverstanden voortvloeien. We zijn bijvoorbeeld geneigd naar keuzemotieven van mensen te vragen terwijl ze zich aan een groep conformeren en, net als iedereen, met de mode meelopen. Om het gedrag van mensen in en rondom organisaties goed te begrijpen, moeten we ook kijken naar de vele sociale verbanden waarin mensen functioneren. De werkgroep (het "team") is daar slechts één van. Aandacht verdient ook de gemeenschap die de informele organisatie vormt, evenals allerlei andere sociale verbanden - groot en klein, vast en veranderlijk - die binnen en buiten te onderscheiden zijn. Ik doel op het bestaan van allerlei groepen in de organisatie waarmee mensen zich identificeren of waartegen ze zich afzetten, op sociale netwerken van vrienden en gelijkgezinden, op het behoren tot dezelfde kerk, politieke partij of etnische groepering, enz. Overigens is het sociale perspectief ook interessant voor managers omdat zij op het collectieve gedrag van medewerkers in het algemeen weinig grip hebben en het niet makkelijk kunnen veranderen.

Collectief gedrag van mensen in organisaties is bepaald geen nieuw onderwerp. Er is zowel door organisatiesociologen en sociaalpsychologen veel aandacht aan besteed. Toch meen ik dat er, door de manier waarop deze disciplines zich ontwikkeld hebben, binnen de organisatiewetenschap een leemte is ontstaan. Organisatiesociologen hebben zich traditioneel vooral geïnteresseerd in organisaties als maatschappelijk fenomeen. De voornaamste theorieën leggen de nadruk op de relatie tussen omgeving en organisatie, het functioneren van de organisatie binnen die omgeving, en algemene principes die de vorm van de organisatie bepalen (bijv. Scott, 2004). Door de keuze van thema's, zoals institutionalisering, agency en macht, blijft er weinig aandacht voor wat er "binnen" organisaties, d.w.z. in de wisselwerking tussen betrokkenen, feitelijk gebeurt. De sociale psychologie stond hier oorspronkelijk dichterbij (Katz \& Kahn, 1978) maar heeft zich in een andere richting ontwikkeld. Het onderzoek heeft zich vooral geconcentreerd op kleine groepen en tweetallen (dyades) en op algemene thema's als rechtvaardigheid, conflict, vertrouwen, identiteit en zingeving, waarmee gedrag in groter verband buiten beeld geraakt is. 
Het gevolg is dat over collectief gedrag de laatste tientallen jaren maar weinig gepubliceerd is.

Collectief gedrag kan in twee brede categorieën ingedeeld worden. De eerste omvat gedrag in het kader van sociale structuren, dat bepaald wordt door rollen en gestuurd wordt door normen, en daardoor redelijk stabiel en voorspelbaar is. De samenwerking tussen leden van een team, communicatie in een vergadering, concurrentie tussen medewerkers van verschillende afdelingen, maar ook gezamenlijk lunchen, verjaardagen vieren, e-mails uitwisselen en roddelen, zijn er voorbeelden van. Er zijn ook bredere sociale structuren die door organisaties heen snijden, zoals het stelsel van arbeidsverhoudingen, dat voorschrijft hoe werkgevers en werknemers met elkaar overleggen en onderhandelen. De tweede categorie omvat gedrag in open situaties waarin geen duidelijke structuur gegeven is en richtlijnen voor gedrag ontbreken. Dit gedrag is vaak veranderlijk en onvoorspelbaar en kent vele verschijningsvormen. Het omvat massaconsumptie, mode, ideologie, morele paniek en massahysterie, die dikwijls onder de noemer "massagedrag" gerangschikt worden. Daarnaast zijn er rellen, plunderingen, opstanden, het elkaar onder de voet lopen bij rampen. Dit wordt ook wel als "kuddegedrag" ("crowding behavior") betiteld; het is grillig, emotioneel en soms vaak gewelddadig. Al deze vormen van collectief gedrag komen met meer of minder regelmaat in organisaties voor en verdienen mijns inziens de aandacht van onderzoekers.

Ik zal een aantal voorbeelden geven die de collectieve dimensie van het gedrag belichten en duidelijk maken waarom die interessant is. Allereerst collectief gedrag in de informele organisatie, zoals zich dat van dag tot dag afspeelt. In tegenstelling tot het individuele gedrag, dat eerder aan de orde kwam, gaat het nu om de samenhang en soms ook de verdeeldheid die blijkt uit het gedrag van informele groepen en van informele leiders en hun volgelingen. Wat aan de oppervlakte komt, in de vorm van zelfvertoon, concurrentie, conflict, protest, sabotage e.d. wordt niet langer aan individuele personen toegeschreven, die als "goede peer" of "rotte appel" gekwalificeerd worden, maar wordt verstaan als uiting van de sociale relaties en processen die zich in de informele organisatie afspelen. Er kan aan worden afgelezen hoe de betrokkenen hun situatie beoordelen, hoe ze hun geschiedenis zien, en wat ze van de toekomst verwachten. Collectief gedrag in de informele organisatie houdt, zoals ik al eerder aangaf, niet op bij de denkbeeldige "grenzen" van de organisatie, maar strekt zich uit tot relaties met "buitenstaanders", d.w.z. mensen die tot andere organisaties (klanten, 
leveranciers) of andere instituties (scholen, vakbonden, beleggers) behoren.

Een bekende vorm van collectief gedrag is concurrentie. Groepen dagen elkaar uit en strijden om middelen en resultaten. Zulk gedrag wordt vanuit de formele organisatie vaak aangemoedigd, gelegitimeerd door de ideologie van de markt. Echter, concurrentie beperkt zich vaak niet tot de officiële tegenspelers. Mensen maken ook onderscheid en zetten zich af groepen waarvoor dat niet zou moeten gelden. Een bekend voorbeeld is de "binnendienst vs. de buitendienst", maar het fenomeen komt op veel grotere schaal voor. In grote bedrijven met een geschiedenis van overnames en fusies, kunnen door de "littekens" die deze in de informele organisatie hebben achtergelaten, vormen van antagonisme overal opduiken.

Wisselwerking met de formele organisatie kan andere vormen van ongewenst collectief gedrag doen ontstaan, zoals discriminatie en agressief gedrag. Het gebeurt als mensen de posities en middelen die hen door de organisatie zijn aangereikt, gebruiken om anderen dwars te zitten of te onderdrukken. Ik heb het nu niet alleen over de manier waarop werknemers elkaar bejegenen maar ook over de omgang met "klanten" - en daaronder vat ik dan ook bijvoorbeeld patiënten, leerlingen, gevangenen. Het zijn vooral "gesloten"organisaties, waarin de klanten beperkt zijn in hun communicatie en bewegingsvrijheid, waar dit gebeurt (Goffman, 1962). Ik hoef de naam "Abu Graib" maar te laten vallen om duidelijk te maken wat ik bedoel. Voorbeelden van zulk collectief gedrag - mishandeling van bejaarden in verpleeghuizen, geïsoleerde opsluiting van psychiatrische patiënten, seksueel misbruik van internaatsleerlingen e.d. - komen met de regelmaat van de klok in het nieuws.

In de categorie massagedrag komen we al snel uit bij het onderwerp modes (of "hypes") en dan in het bijzonder bij de zgn. "management modes". Hoewel $u$ het misschien niet zou verwachten, gezien het geïdealiseerde beeld van de autonoom handelende manager, is in onderzoek aangetoond dat managers zich op grote schaal laten leiden door wat hun collega's doen (Abrahamson \& Fairchild, 1999). Of het nu om strategie, leiderschap of human resources gaat, managers willen allemaal de laatste trend volgen - soms tot wanhoop van stafmedewerkers die het allemaal moeten uitvoeren en lijnmedewerkers die het over zich heen krijgen. Het gevolg is dat ook organisaties als geheel elkaar nadoen: als binnen een bepaalde sector een bedrijf aan afslanking begint, is de kans groot dat andere bedrijven volgen (vgl. 
"institutioneel isomorfisme", DiMaggio \& Powell, 1983). Dit is eigenlijk het enige terrein waarop massagedrag in organisaties is en wordt onderzocht, vermoedelijk omdat dit soort na-aperij voor de partijen die erbij betrokken zijn kostbare consequenties kan hebben.

Minder in het oog springend maar niet minder invloedrijk, zijn ideologieën. Dit zijn bundels van ideeën over hoe de wereld in elkaar zit, wat tot wat leidt, en hoe te handelen, gebaseerd op bepaalde waarden of principes. Ideologieën worden door de dragers ervan als vanzelfsprekend en simpelweg "waar" ervaren, waardoor ze verheven zijn boven discussie en empirische toetsing. Een bekend voorbeeld is de ideologie van de markt, die uitgaat van de gedachte dat marktwerking goed is en zoveel als mogelijk dient te worden toegepast - niet alleen in het bedrijfsleven, maar ook in de gezondheidszorg, het onderwijs, de welzijnssector. Hoe vaak ook blijkt dat dit niet zo is en dat de markt aan "beperkingen" lijdt, het idee blijft onaantastbaar. Ideologieën berusten op geloof, niet op feiten, en vertonen daardoor soms onlogische elementen. Een bekende gedachte uit de ideologie van de markt is bijvoorbeeld dat bedrijven om te overleven concurrentievoordeel op andere bedrijven moeten behalen. Logisch gezien is het onmogelijk dat alle bedrijven binnen een sector concurrentievoordeel op elkaar behalen. Maar afgezien daarvan is het om voort te bestaan helemaal niet nodig dat bedrijven concurrentievoordeel behalen; dat is ook mogelijk door elk in een eigen gebied te opereren of door samen te werken. En wat te denken van de stelling dat topmanagers hoge bonussen verdienen omdat de markt nu eenmaal zo in elkaar zit. Het heet dat topmanagers hoge bonussen toekomen als beloning voor betere bedrijfsresultaten, maar ook als beloning voor extra inzet om slechtere bedrijfsresultaten weg te werken; een ongerijmde redenering die tot self-fulfilling prophecy is geworden. Hoewel ideologieën vaak een lang leven is beschoren en ze daardoor veel invloed hebben, is hun levensduur niet onbeperkt. We zien op dit moment dat de economische crisis de ideologieën van markt, globalisering en financieel kapitalisme aan het wankelen brengt, hetgeen mogelijk tot verschuivingen leidt en nieuwe ideologieën kan doen ontstaan. Een goed moment voor onderzoek!

Een belangrijk facet van ideologieën is dat ze "gesloten" zijn en verlammend werken. Ze ontmoedigen aanhangers om andere denkbeelden te exploreren en andere acties te ondernemen. Een voorbeeld is wat in een recent krantenartikel van "het kleine denken van de hulpverlener" is genoemd, waarbij hulpverleners in reïntegratiesector uitgaan van de veronderstelde hulpeloosheid van cliënten en daarmee een self-fulfilling prophecy oproepen. Dit staat een andere benadering, 
bijvoorbeeld op basis van activering van de cliënt, in de weg (Solinger \& Ezerman, 2009).

Weinig besproken, maar wel goed zichtbaar is het gedrag van sociale klassen. Het begrip sociale klasse wordt weinig gebruikt omdat het een beladen historie heeft en zich moeilijk verdraagt met de ideologie van gelijke burgers. Toch kost het weinig moeite om te zien hoe mensen zich in sociaal-economisch opzicht van elkaar onderscheiden en dit onderscheid op allerlei manieren accenturen. Dat er in organisaties verschillen zijn tussen de hogere en middelste lagen van het management, en tussen managers en gewone medewerkers is evident. Interessanter is wat aan de grenzen gebeurt. Aan de ene kant zien we uitingen van zelfverheerlijking en opportunisme, evenals pogingen vanuit de hogere klasse om bestaande verschillen te legitimeren en in stand te houden. Aan de andere kant zijn er incidenten waarin de lagere klasse de confrontatie zoekt en de privileges van de hogere klasse aanspreekt. In de kwestie van "bonussen van de top" is dit spel goed te volgen. Het fenomeen van exorbitante beloningen bestaat al jaren, maar kon altijd vanuit de ideologie van de markt gelegitimeerd worden. Nu die ideologie aan geloofwaardigheid verliest, zien we een massale reactie waarbij het tot voor kort geaccepteerde patroon als "collectieve hebzucht" van managers wordt afgeschilderd en wordt aangevochten. Het is maar één voorbeeld, maar illustreert duidelijk dat klassegedrag aan de orde van de dag is.

Een ander interessant onderwerp is collectief gedrag van medewerkers ten opzichte van hun organisatie. Het belang ervan blijkt wel uit de managementretoriek rond het thema betrokkenheid. Van medewerkers wordt verlangd dat ze zich met "hun" organisatie - hoe groot en divers ook - identificeren, dat ze zich erbij betrokken voelen, dat ze de waarden ervan overnemen en dat ze zich loyaal gedragen; vaak wordt gezegd: dat "hun neuzen dezelfde kant uitstaan". In hun werk, dat per definitie van inhoud verschilt, mogen mensen divers zijn, maar daarbuiten wordt een grote mate van uniformiteit verwacht. Ze moeten zich als "burger" van de organisatie gedragen. Of dit ook het geval is, is een andere zaak. We weten uit onderzoek dat medewerkers vaak heel anders over hun organisatie denken, sceptisch of cynisch zijn, de regels van de organisatie aan hun laars lappen, of zelfs sabotage plegen. Voor een deel is het massagedrag wat hier optreedt, voor een deel kuddegedrag waarin mensen zich laten leiden door wat er voorvalt.

Deze combinatie treffen we ook aan bij organisatieverandering. Of het nu om herstructurering, inkrimping, "outsourcing", of "process 
reengineering" gaat, veranderingen in de formele organisatie die door het management geïnitieerd en geconcipieerd worden, zijn voor medewerkers gewoonlijk verrassend en bedreigend. De reacties die dit oproept zijn steevast dezelfde: medewerkers zoeken bij elkaar naar steun en verklaringen van het wat en waarom, er komt een geruchtenen roddelcircuit op gang, er ontstaat informeel leiderschap, kortom, er ontstaat een heel spectrum van gedragingen waarbij mensen zich gezamenlijk manifesteren en zich verzetten, zich terug trekken, of lijdzaam verzet plegen. Daarnaast is er kuddegedrag, in de vorm van demonstraties, bezettingen, stakingen, die eventueel uit de hand kunnen lopen en resulteren in rellen. Het is gebruikelijk om dit allemaal onder de noemer "weerstand tegen verandering" te scharen, maar veel inzicht geeft dat niet. Het is vruchtbaarder om het als collectief gedrag op te vatten en te bestuderen wat er achter zit en ook hoe het zich in de tijd ontvoortstuwt.

Veel eigen onderzoek om op te bogen heb ik niet. Wel heb ik me in de loop van de jaren beziggehouden met onderwerpen die zijdelings raken aan wat ik noemde. In mijn promotieonderzoek heb ik onderzoek gedaan naar politieke ideologieën en hun aanhang onder studenten in de late jaren 60 (Roe, 1975). In de jaren 90 heb ik me o.a. bezig gehouden met de teloorgang van de Communistische ideologie en de verbreiding van de marktideologie in Oost-Europa, in het bijzonder Bulgarije en Hongarije, en de invloed daarvan op werknemers (Roe, 1994; Roe, Zinovieva, Dienes, \& Horn, 2001). Naar aanleiding van martelpraktijken en gifschandalen uit de jaren 70 heb ik, in de tussentijd, nog een theoretische studie gedaan het fenomeen institutionele criminaliteit. Een conclusie was dat wat steevast als "incidenten" wordt afgeschilderd, een voorspelbaar resultaat is van collectieve activiteit die optreedt in bepaalde typen organisaties (gesloten, slecht afgebakende rollen, grote afhankelijkheid enz.) (Roe, 1981). Houding en gedrag van mensen in organisaties zijn binnen mijn onderzoeksgroep veel onderzocht, maar niet voldoende vanuit een collectieve invalshoek. Ik noemde al voorbeelden van onderzoek naar cynisme en roddel. Tenslotte is er nog wat theoretisch werk van zeer recente datum: een kritische beschouwing over de theorie van betrokkenheid ("organizational commitment") en ideologische elementen daarin (Roe, Solinger, \& Van Olffen, 2009), en een studie waarin de zgn. "upper echelons theorie" op de korrel wordt genomen (Raes, Heijltjes, Glunk, \& Roe, 2008). Dit is een theorie die het succes van organisaties toeschrijft aan het gedrag van het topmanagement. Het is in feite een klassetheorie, beperkt tot de hoogte klasse, die erom vraagt aangevuld te 
worden met theorie over de middenklasse en de lagere klasse, die er nog altijd voor zorgen dat het uitvoerende werk gedaan wordt.

Onderzoek naar collectief gedrag wijkt af van ander onderzoek omdat men eerst de overeenkomsten in gedrag in beeld brengt en pas daarna de collectiveiten die dat gedrag vertonen. Het is te zien als een "omgekeerde werkwijze", men kijkt niet naar het gedrag van bepaalde groepen, maar speurt naar groepen door middel van hun gedrag. Verder is het gedrag zeer divers en dynamisch; dikwijls ook ongearticuleerd, verborgen en grootschalig. Om dit type onderzoek te kunnen uitvoeren zal het arsenaal aan methoden flink uitgebreid moeten worden met o.a. methoden uit antropologie, linguïstiek, economie, communicatiestudies en politieke wetenschap. Wat er interessant aan is, zijn niet alleen het bestaan en het verloop van het gedrag, maar ook de drijvende krachten erachter en de effecten ervan. Uiteindelijk gaat het om de vraag hoe individueel en collectief gedrag op elkaar inwerken en waar het omslagpunt ligt tussen zelfstandig handelen als individu en meelopen met de massa.

Samenvattend: Hoe verknocht we ook zijn aan het beeld van de mens als individu, veel van het menselijk gedrag is collectief gedrag. Mensen doen wat anderen doen, ze denken wat anderen denken - ook in organisaties. Waar scheidslijnen liggen, vieren ze hun eigenheid en zoeken de confrontatie met anderen. In de samenleving willen we er niet van horen en prediken we het ideaal van gelijke en autonome burgers die in liberale harmonie hun eigen beslissingen nemen. Voor de organisatiewetenschap is het echter geen optie hierin verder mee te gaan en de studie van collectief gedrag langer te verwaarlozen. Juist in deze tijd, waarin mensen zich als massa's en kuddes manifesteren, moet het collectieve gedrag - inclusief de onuitgesprokene, irrationele, illusoire en destructieve aspecten ervan - weer tot onderwerp van studie worden gemaakt. Pas als we zien hoe het collectieve en het individuele samenkomen, zijn we op de goede weg.

\section{Wij en de wereld}

Wie voor het eerst kennismaakt met ons vakgebied, zou denken dat de organisatiewetenschap louter een aangelegenheid is van Engels sprekende en vooral schrijvende mensen. En wie de moeite neemt de citatiepatronen te analyseren, zou tot de conclusie komen dat het Mekka van onze discipline aan de Oostkust van de Verenigde Staten ligt. Wij merken het nauwelijks meer op, maar toch zou dit bevreemding moeten wekken. Organisaties kwamen en komen overal ter wereld voor en kennis 
over organisaties was en is op alle continenten aanwezig. Hoe zit het dan met onze kennis? Heeft die alleen betrekking op het bedrijfsleven en overheden in de westerse wereld, of geldt zij ook op andere plaatsen in de wereld? Weten we eigenlijk wel hoe het er in andere werelddelen aan toe gaat? Zijn organisaties elders te vergelijken met de onze? Komt het gedrag van mensen in Siberië, Ruanda en Peru overeen met dat wat wij over de Europeanen gedocumenteerd hebben? Zijn de principes van onze wetenschap universeel?

Het is niet moeilijk om in te zien dat onze wetenschappelijke kennis onvolledig is en dat we niet weten hoever de geldigheid ervan reikt. Maar we moeten wel een zekere gêne overwinnen om dit te erkennen. Die gêne heeft niet zozeer betrekking op onze onwetendheid zelf - er zijn immers altijd grenzen aan kennis - maar eerder op het gebrek aan belangstelling dat erin tot uitdrukking komt. Immers, wie van ons heeft er behoefte aan te weten hoe het er in de suikerindustrie van Sulawesi of het onderwijs in Colombia aan toe gaat? Nog gênanter is misschien het gevoel dat we ons er niet in hoeven te verdiepen, omdat we onze theorieën en methoden als superieur beschouwen en, "locale uitzonderingen" daargelaten, als algemeen geldig. Vooringenomenheid en zelfgenoegzaamheid zijn - hoewel bepaald geen wetenschappelijke waarden - onder wetenschappers helaas eerder regel dan uitzondering. Redacties van internationale wetenschappelijke (lees: engelstalige) tijdschriften zijn uiterst terughoudend met het publiceren van nietwesters onderzoek. Wat ervan doordringt is als gevolg daarvan geschreven door mensen die het Engels goed meester zijn, zich van het westerse vakjargon bedienen en minimaal voortbouwen op westerse theorieën. Het zou geen probleem hoeven te zijn als er onder ons voldoende wetenschappers zouden zijn die in staat zouden zijn om publicaties in andere talen te lezen en zouden beseffen hoe het er elders aan toe gaat. Maar aan die talenkennis en de interesse om erachter te komen hoe andere wetenschappers over hun wereld en de onze denken, ontbreekt het juist.

De pijnlijke situatie waarin wij ons met dit wetenschappelijk chauvinisme bevinden, doet zich niet alleen in onze discipline voor maar ook op andere terreinen van wetenschap. In de psychologie, waarop de organisatiewetenschap in belangrijke steunt, was jarenlang sprake van een intellectueel eenrichtingsverkeer van de Verenigde Staten naar de rest van de wereld. Wat de moeite waard was om te onderzoeken, welke theorie moest worden gebruikt, hoe het moest worden opgeschreven en of het kon worden gepubliceerd, werd in Amerika bepaald. Wat 
niet uit Amerika kwam of daar niet als belangrijk gezien werd, deed eenvoudigweg niet terzake (Brock, 2006). Over de sociologie is hetzelfde gezegd (Connell, 2007). De laatste jaren zijn tekenen van een kentering te zien, waarbij vooral onderzoekers uit Europa, Australië en Azië zich manifesteren, zij het zich nog steeds schikkend naar de regels van de zgn. "internationale wetenschap". Zonder problemen is dit niet omdat het van onderzoekers vraagt dat ze door een westerse bril naar hun object kijken en zich distantiëren van locale zienswijzen ook als die meer betekenisvol zijn, waardoor voor ons veel potentiële kennis verloren gaat.

Volgens de antropoloog Trouillot (2003) is deze stand van zaken kenmerkend voor de westerse benadering van wetenschap in het algemeen en berust zij op een koloniale denkwijze die teruggaat naar de 15e eeuw. Zij is uitdrukking van wat hij "een geografie van de verbeelding" noemt, een denkwijze die de wereld indeelt in "the West and the Rest". Het Westen geldt hier - hoewel in feite tot het Noord-Atlantische gebied beperkt - als het vanzelfsprekende centrum van de wereld waar historie, cultuur, kennis en macht geconcentreerd zijn. De Rest is alles wat niet-westers is, het deel van de wereld dat bevolkt wordt door mensen zonder oordeelsvermogen, beschaving en geschiedenis (Wolf, 1982). In ons denken classificeren we ze eigenlijk nog steeds als "wilden" (Trouillot spreekt van "the savage slot") die een onbereikbaar exotisch paradijs bewonen of, als ze echt macht verwerven, een bedreiging voor ons vormen. Bestudering van de Rest is, binnen deze optiek, primair een opgave van cultureel antropologen (uiteraard opgeleid en afkomstig uit het Westen), die nu eenmaal tot de studie van het "verre en vreemde" geroepen zijn. Voor andere wetenschappers bestaat eigenlijk geen noodzaak om de "anderen" en hun samen levingen te onderzoeken, omdat westerse kennis nu eenmaal als universeel wordt ervaren, of het of het moest zijn om exotische interesses te bevredigen. De enige concessie die we willen doen, is gegevens die uit andere landen komen als varianten op ons bekende patronen te zien, mits ze verzameld zijn op de door ons aangegeven manier en we ze kunnen toeschrijven aan wat wij "cultuur plegen te noemen. Er zijn op organisatieterrein vele voorbeelden te geven van wat mijn collega Benhard Wilpert "safari-onderzoek" pleegde te noemen, zoals het cultuuronderzoek van Hofstede (1980) en Schwartz (S. H. Schwartz, 1992) en het onderzoek naar leiderschap van House en anderen (2004). De begrippen en het instrumentarium komen uit het Westen, de helpers gebruiken ze om gegevens te verzamelen in den verre, en daarna worden ze volgens bekende recepten verwerkt in comparatief onderzoek voor een overwegend westers publiek. 
Wanneer wetenschappers die aan dit type onderzoek deelnemen een eigen visie of eigen analyse willen presenteren, kan dat, mits ze het niet te bont maken. Er bestaat echter geen behoefte aan een eigen wetenschap vanuit de Rest, laat staan aan een wetenschap die de westerse manier van wetenschap bedrijven, inclusief de opleiding van onderzoekers, inkadert in koloniale praktijken en hun geschiedenis, en tot onderwerp van eigen zogenaamd "indigenous"onderzoek maakt. Het geeft ons een ongemakkelijk gevoel. Dus praten we er liever niet over en hullen ons in "postkoloniale stilte". Dat geldt niet alleen voor de wetenschap in het algemeen, maar zeker ook in de organisatiewetenschap.

Ik voel uw aarzeling. Is het niet overdreven om dit zo scherp te stellen? Valt het niet "best mee" met ons begrip van de wereld? Als Chinezen en Indiërs de moeite nemen om in westerse tijdschriften te publiceren en dezelfde begrippen gebruiken als wij, is er toch geen reden om ons zorgen te maken? Ik ben er niet gerust op. Er ontbreken in onze vakliteratuur te veel namen, instituten en nationaliteiten om in deze gedachte mee te gaan. Bovendien ben ik me bewust van hoe het met ons in Europa gelopen is. Wij Nederlanders hebben het in de "internationale" wetenschappelijke pers helemaal gemaakt, maar het heeft heel wat moeite gekost en we hebben er veel voor moeten wegmoffelen. Duitse, Zweedse en Spaanse collega's zijn redelijk op weg, maar wat te zeggen van de Fransen, de Italianen, de Tsjechen, de Kroaten en al die andere Europeanen? Wat is de status van hun eigentalige wetenschap? Wat gebeurt daar straks mee als zij ook tot de Angelsaksische liga zijn doorgedrongen? Ik heb het dan niet eens over wetenschappers in het Midden-Oosten, Afrika en Zuid-Amerika. Voordat we het onderwerp naar de prullenbak verwijzen is het misschien goed om eens een zelftest te doen op onze bereidheid om tijd te steken in het lezen van publicaties uit China, Iran, Brazilië of Namibië. Ik hoor de vraag al: "hebben ze daar wetenschap?" Of publicaties over China, Iran, Brazilië of Namibië. Of een test op hoe wij denken over publicaties uit samenlevingen die niet democratisch bestuurd worden en waar stammen een centrale rol spelen. Stammen? Meer primitief kan het in onze ogen bijna niet. Wie zou daar nu iets over willen leren?

In mijn ogen is er wel degelijk iets aan de hand en het wordt tijd om daar iets aan te doen. Heel gemakkelijk zal het niet zijn om ons voor de wereld open te stellen, omdat we onze manier van denken en handelen zullen ingrijpend moeten veranderen. De hiërarchie" waarin wij ook in de wetenschap gewend zijn - "hoe westerser hoe beter" - zal plaats moeten maken voor horizontale manier van werken, 
waarin we onze benaderingen en onze kennis op hetzelfde plan zetten als die van wetenschappers uit andere culturen. Daarbij zullen we een ongemakkelijke fase moeten doormaken, waarin we zullen horen wat anderen vinden van de "narratives of the West" en onze wetenschappelijke praktijken. We zullen merken dat zoals wij in Westen het "oriëntalisme" hebben uitgevonden (Said, 1978), anderen ons als "inboorlingen van het Westen" zullen onderbrengen in hun beeld van "occidentalisme". Onze kennis zal van universeel tot Noord-Atlantisch of Europees gedegradeerd worden en geplaatst worden naast Eastern en Southern theory. Overdreven? Misschien wel, maar het is geen grapje. De aanzetten zijn er al (bijv. Connell, 2007) en het zou naïef zijn te denken dat met de veranderende verhoudingen in de wereldeconomie, zeker na de crisis van nu, de opkomende machten bereid zullen zijn zich te blijven voegen in patronen die in Europa en Amerika bedacht zijn.

Wat moeten we er nu mee als westerse wetenschappers? Want per slot van rekening zijn we als Nederlanders nog steeds deel van het westerse wetenschappelijke Emporium. Waar we mee zullen moeten beginnen is "particulariseren", het laten varen van universalistische pretenties, oftewel openlijk aangeven van de begrenzingen van onze theorie en de condities waaronder het onderzoek plaats vindt. We zullen moeten erkennen dat Nederlandse werknemers en bedrijven op wereldschaal net zo veel, of liever net zo weinig, betekenis hebben als hun tegenvoeters in Oeganda, Korea of Panama, en eigenlijk ook die in Wisconsin of Utah. Verder moeten we ons meer open stellen voor andere ideeën; zeker, er komen veel goede ideeën uit de Verenigde Staten en Engeland, maar er is in de wereld van wijsheid meer te koop. Belangrijker nog is het te komen tot andere manieren van samenwerking: de tijd van de safari's is voorbij. Samenwerking kan ook op basis van gelijkwaardigheid en verscheidenheid, met uitwisseling in plaats van eenrichtingsverkeer. Er hoeft geen centrale regie te zijn en het resultaat hoeft niet eenvormig te zijn. Ik ben voorstander van pluriformiteit: concepten die niet ons denkschema passen of die aangeven waar het tekortschiet, zijn wat mij betreft juist welkom omdat ze ons iets nieuws leren en inzicht bieden in onze beperkingen en zwakke plekken. Ik bepleit niet dat we onze eigen wetenschap aan die van anderen ondergeschikt moeten maken. We doen niet voor niets zoveel moeite. De maatschappelijke waarden die zij vertegenwoordigt en het vermogen om te feiten verklaren en de werkelijkheid effectief te veranderen - in elk geval onze feiten en onze werkelijkheid - maken het de moeite waard haar bekendheid te blijven geven en verder te ontwikkelen. Maar dan 
geplaatst naast de wetenschap van anderen, die deze eigenschappen ook bezit, zodat we samen méér weten.

Natuurlijk is de koerswijziging waar ik over praat er een die de onze mogelijkheden als organisatiewetenschappers uit de Rijndelta te boven gaat. Er is een verandering van diepgewortelde institutionele patronen voor nodig, waar wetenschappers uit alle werelddelen en vele disciplines bij betrokken zijn, wijzelf inbegrepen. Hoeveel tijd er zal verstrijken voordat er van enige gelijkwaardigheid gesproken kan worden, valt niet te zeggen. Ik kan wel een aantal concrete veranderingen aangeven die mijns inziens bijdragen aan de koerswijziging. Allereerst liberalisatie van de internationale wetenschappelijke tijdschriften - tot nu toe centrale filter- en distributiepunten voor wetenschappelijke kennis - in de zin dat redacties breder worden samengesteld en werk uit een groter geografisch gebied wordt geaccepteerd. Er is al een tendens in deze richting gaande, maar deze kan zeker nog verder doorgezet worden. Het kan de culturele vooringenomenheid verminderen en de kijk op het vakgebied verbreden. Omdat de capaciteit van de huidige tijdschriften volstrekt onvoldoende is om een groter aanbod van studies en een grotere verscheidenheid in taal en context te kunnen accommoderen, zal het hier niet bij kunnen blijven. Regionale tijdschriften, die grote gebieden (Azië, Latijns Amerika, de Pacific, het Midden-Oosten, Afrika, het Caribisch gebied) omvatten kunnen een belangrijker rol gaan vervullen en in aantal en oplage toenemen, een trend die ook al zichtbaar is.

Overigens is te verwachten dat de rol van het wetenschappelijke tijdschrift, dat onder controle staat van een uitgever en een redactie, op den duur zwakker zal worden en dat het belang van elektronische media die via Internet toegankelijk zijn zal toenemen. Ook dit zien we al gebeuren met de opkomst van Internet-tijdschriften waar geen uitgever meer aan te pas komt, eigen uitgaven van universiteiten en individuele onderzoekers, en media als wikipedia en wikibook, die steeds serieuzer worden. Een belangrijk verschil met de traditionele media is dat de nieuwe media in diverse talen kunnen verschijnen, wat niet alleen de verspreiding ten goede komt maar ook een betere contextualisering mogelijk maakt en de relevantie van kennis vergroot. Bij de verbeterde raadpleging en benutting van kennis, spelen zoekmachines een niet weer weg te denken rol. Hier ligt een mogelijkheid om taalbarrières te slechten: als zoekmachines zodanig ingericht worden dat ze zoektermen automatisch vertalen, kan de gebruiker geattendeerd worden op en toegang krijgen tot anderstalige bronnen. De technologie van Internet biedt ongetwijfeld de veel ruimte voor verdere ontwikkelingen bijvoorbeeld via sociale 
computernetwerken (Facebook, MySpace, Hyves, LinkedIn e.d.) en via persoonlijke websites, blogs, forums, nieuwsbrieven e.d.

Of westerse onderzoekers ook in alle deze media willen en kunnen publiceren, is een andere kwestie. Hier komen we een institutionele barrière tegen, namelijk het statussysteem dat academische instellingen in Amerika en Europa gebruiken om publicaties en daarmee onderzoekers te waarderen. Hoewel het van binnenuit beschouwd zeker voordelen heeft, gaat er een krachtige bevestiging van koloniale verhoudingen van uit. Hier zal iets aan moeten veranderen om het werk van niet-westerse onderzoekers gewaardeerd te krijgen en om westerse onderzoekers zover te krijgen dat ze in niet-westerse media willen publiceren. Om dat te kunnen moet nog een barrière overwonnen worden, namelijk die van de taal. Ik stel me voor dat vertaaldiensten, in toenemende mate gebaseerd op automatisch vertalen, hierbij kunnen helpen. Hiernaast zal het, om over de grenzen van landen en continenten onderzoek te kunnen doen en te kunnen communiceren, nodig zijn om meerdere talen te leren, en wel zodanig dat men in meerdere talen kan lezen en schijven. In Nederland en andere Europese landen is dat, voor een deel van de onderzoekers al het geval, maar in veel andere landen, Amerika en Engeland voorop, zijn vele wetenschappers buiten hun taalgebied in feite analfabeet. Kennis van andere talen is niet voldoende; waar minstens zoveel behoefte aan bestaat, is kennis van de geschiedenis en actualiteit met betrekking tot andere samenlevingen. Ook wat dit betreft is, er ook nog veel winst te behalen.

Dan nog een woord over wetenschappelijke organisaties en congressen. Deze instituties weerspiegelen grotendeels de patronen die op het westerse wereldbeeld gebaseerd zijn. Met de toenemende welvaart en mobiliteit neemt de diversiteit van congresdeelnemers toe en daarmee onstaat een druk om te diversifiëren, d.w.z. meer samenwerkingsverbanden en ontmoetingsplaatsen te creëren. Ik verwacht dat de eerder genoemde trends ertoe kunnen leiden dat hierdoor ook meer evenwicht komt in de onderwerpen die aangesproken worden en de taal waarin dit gebeurt. Als ik het goed zie, zal het de betekenis en relevantie van de organisatiewetenschap zoals die in de wereld bedreven wordt, kunnen vergroten.

Samenvattend: Dat bedrijven en staten uit het Noord-Atlantische gebied, eerst Europa en later Amerika, de wereld overheerst hebben, is geen nieuws. Maar dat de koloniale geschiedenis niet is afgesloten en voortleeft in de praktijken van vandaag, zeker ook in de wetenschap, wordt onvoldoende erkend. Daardoor zien we niet welke verhoudingen 
er in de wereld van vandaag zijn en hoe die onze kennis beïnvloeden en beperken. Het proces van globalisering, waarin financiële markten de regie over de wereldwijde productie en commercie hebben overgenomen, handhaaft en bevestigt de geografie van de verbeelding waarin het denken van de "West" superieur is aan het denken van de "Rest". Daar moet iets in veranderen. We zullen de grenzen van onze kennis moeten leren zien en toe moeten naar een wetenschap die gekenmerkt wordt door openheid, samenwerking en pluriformiteit.

\section{Ter afronding}

Dit alles samen nemend, zou ik willen zeggen: "zo kan het ook". We kunnen organisaties ook zien als het product van mensen, van wat mensen denken en doen; niet alleen als een entiteit waar mensen onderdeel van uitmaken. We kunnen ook studie maken van wat er gebeurt, niet alleen van wat we denken dat er is. We kunnen de mens ook zien als massa- of kuddedier, en niet alleen als individu. En we kunnen in de geschiedenis en in de wereld verder kijken dan onze neus lang is. Ik denk dat van een organisatiewetenschap die zich dit realiseert veel te verwachten is.

Om dit college niet te lang te laten duren, wil ik het hierbij laten en de resterende tijd gebruiken om kort iets zeggen over de betekenis van dit alles voor de praktijk en voor de opleiding van studenten. Organisatiewetenschap heeft niet alleen tot doel organisaties beter te begrijpen, maar ook ze te helpen vormgeven, veranderen en besturen, zodanig dat ze adequaat kunnen functioneren en op de mensen die ermee te maken een gunstige uitwerking hebben. Mijn betoog houdt de belofte in dat de praktijk profijt zal hebben van meer, en vooral ook ander, onderzoek. Wie daar niet op wil of kan wachten en om zo te zeggen "boter bij de vis wil", kan ook nu al op ons rekenen. Er is een uitgebreide "body of knowledge" over structuur, cultuur, management, leiderschap, teamwerk, sociale verhoudingen, functieontwerp, selectie, opleiding en carrière, waar velen met succes gebruik van maken. Het zijn overigens onderwerpen waaraan ikzelf, alles bij elkaar, in mijn loopbaan meer tijd heb besteed dan aan datgene waar dit college over ging.

Belangrijk is wel dat deze kennis, net als de kennis die nog moet komen, alleen via een vertaalslag voor de praktijk nuttig te maken is. Ik zeg dat omdat sommige collega-wetenschappers klaar staan om managers tot "evidence-based practice" te verleiden, terwijl managers van hun kant graag eenvoudige aanwijzingen en modellen hebben die ze direct kunnen toepassen - het liefst zgn. "best practices" die elders 
hun nut bewezen hebben. In mijn ervaring werkt dat niet zo: elk bedrijf en elke situatie zijn uniek, waardoor de condities waaronder de kennis moet werken vrijwel altijd afwijken van de condities waaronder de kennis verworven is. Elke toepassing vergt eerst een goede, kritische en creatieve analyse, en vervolgens een synthese - maatwerk dus waarin al datgene wat nuttig is tot de juiste oplossing wordt samengesmeed. Het is te zien als en "ontwerpproces" waarin de manager zelf, of een wetenschapper die de situatie voldoende kent, tot een werkbare oplossing komt. Daarbij moet dan in elk geval, ook al is de wetenschap nog bezig met onderzoek, rekening gehouden worden met de menselijke kant, het veranderlijke, het collectieve en het maatschappelijke kader.

Dit heeft ook repercussies voor de opleiding van studenten. Naast de kennis die zij aangedragen krijgen en die met de tijd mee evolueert, zouden zij vooral een kans moeten krijgen om echt kritisch en creatief te leren denken. Ik heb ervaren dat de ontwerpbenadering, die ik indertijd nog geleerd heb mijn Delftse collega Johannes Eekels, voor studenten, ongeacht hun studierichting, erg nuttig is en ze uitstekend voorbereidt voor de praktijk. Wat ik verder nog kan aanbevelen is studie van de geschiedenis en actualiteit - een student hoort de krant te lezen en zich van de wereld waarin we leven en werken een beeld te kunnen vormen. En tenslotte dan nog talen. Ik juich het zeer toe dat de Universiteit Maastricht besloten heeft om studenten de gelegenheid te bieden om vreemde talen te leren. Het geeft het beste paspoort voor de wereld. 


\section{Dankwoord}

Tenslotte wil ik een persoonlijk woord richten tot degenen met wie ik in de afgelopen 40 jaar heb samengewerkt. Daarbij moet ik me dan wel beperken, omdat het om zeer veel mensen gaat, in Nederland, elders in Europa, en in andere werelddelen. Het belangrijkste wat ik te zeggen heb, is dat ik het een voorrecht heb gevonden met zoveel aardige en talentvolle mensen te mogen samen werken. Ik heb het over studenten, assistenten, medewerkers, collega's uit allerlei disciplines, mensen uit bedrijfsleven en overheid. Als ik iets geleerd heb, inspiratie heb gevonden, geholpen ben, is dat vooral door die contacten. Ik heb er van genoten, ben er dankbaar voor en ben blij aan veel van die contacten nog geen einde komt.

Een speciaal woord van dank wil ik - wel een beetje laat - uitspreken aan mijn leermeesters: Hubrecht Duijker, Adriaan de Groot, Sies Wiegersma en Adriaan Kortlandt. Ik heb met het verstrijken van de dagen ingezien hoezeer ik door hun beschouwende, kritische, en pragmatische instelling gevormd ben en hoeveel ik met datgene wat zij mij hebben aangereikt, heb kunnen doen.

Ik het heel prettig gevonden om de laatste jaren aan de Universiteit Maastricht te mogen werken. Zonder ook maar iets ongunstigs over de Universiteit van Amsterdam, de Technische Universiteit Delft, de Universiteit van Tilburg en de Radboud Universiteit Nijmegen te willen zeggen, waar ik ook met veel plezier heb gewerkt, moet mij van het hart dat de werksfeer en de samenwerking hier wel zeer bijzonder zijn. Ik wil de universiteit in de persoon van Rector Gerard Mols en de faculteit in de persoon van Decaan Jos Lemmens hiervoor hartelijk dank zeggen. Heel veel dank ben ik ook verschuldigd aan de mensen in mijn naaste omgeving met wie ik de laatste jaren zo prettig en vruchtbaar heb samengewerkt: Adela, Anneloes, Bart, Bas, Boris, Cas, Daniela, Esther, Fons, Fred, Hannes, Jia, John, Kitty, Maarten, Marielle, Mark, Martin, Mary, Mieke, Nicolle, Omar, Peter, Sara, Sjir, Stewart, Stuart, Ursula, Walter, Wil en Woody.

Tenslotte is er het thuisfront dat mij in alles wat ik heb ondernomen aangemoedigd en gesteund heeft. Ik dank Dorothy, mijn kinderen Angela en Tony, en mijn vrouw Marika, die mijn leven tot een complete vervulling heeft gemaakt.

Ik dank u voor uw aandacht. 


\section{Literatuur}

Abrahamson, E., \& Fairchild, G. (1999). Management fashion: Lifecycles, triggers, and collective learning processes. Administrative Science Quarterly, 44, 708-740.

Ancona, D. G., Okhuysen, G. A., \& Perlow, L. A. (2001). Taking time to integrate temporal research. Academy of Management Review, 26(4), 512-529.

Bentein, K., Vandenberg, R. J., Vandenberghe, C., \& Stinglhamber, F. (2005). The role of change in the relationship between commitment and turnover: A latent growth modeling approach. Journal of Applied Psychology, 90(3), 468-482.

Bluedorn, A. C. (2002). The human organization of time. Temporal realities and experience. Stanford, CA: Stanford University Press.

Blumberg, B. F., Peiró, J. M., \& Roe, R. A. Trust and social capital: A dynamic view. In F. Lyon, G. Möllering, M. Saunders \& T. Hatzakis (Eds.), Handbook of Research Methods on Trust (in preparation).

Breedveld, K. (2001). Trends in de tijd: een schets van recente ontwikkelingen in tijdsbesteding en tijdsordening (Vol. SCP-publicatie, ISSN 1568-1262; 2001/5 ). Den Haag: Sociaal en Cultureel Planbureau

Brock, A. C. (Ed.). (2006). Internationalizing the history of psychology. New York: New York University Press.

Claessens, B. J. C. (2004). Perceived control of time: Time management and personal effectiveness at work. . (PhD Thesis). Eindhoven: Eindhoven University of Technology.

Claessens, B. J. C., Van Eerde, W., Rutte, C. G., \& Roe, R. A. (2004). Planning behavior and perceived control of time at work. Journal of Organizational Behavior, 25(8), 937-950.

Claessens, B. J. C., Van Eerde, W., Rutte, C. G., \& Roe, R. A. (2007). A review of the time management literature. Personnel Review, 36, 255-276. 
Clegg, S. R., Courpasson, D., \& Phillips, N. (2006). Power in organizations. Thousand Oaks, CA: Sage.

Connell, R. (2007). Southern theory: The gobal dynamics of social science. Cambridge, UK: Polity.

Cooper, C. L., \& Clegg, S. (Eds.).(2008). The Sage handbook oforganizational behavior: Sage Publications.

DiMaggio, P. J., \& Powell, W. W. (1983). The iron cage revisited: Institutional isomorphism and collective rationality in organizational fields. American Sociological Review, 48(2), 147-160.

Egan, G. (1994). Working the shadow side: A guide to positive behind-thescenes management. San Francisco, CA.

George, J. M., \& Jones, G. R. (2000). The role of time in theory and theory building. Journal of Management, 26(4), 657-684.

Gersick, C. J. G. (1989). Marking time: Predictable transitions in task groups. Academy of Management Journal, 32, 274-309.

Gevers, J. M. P. (2004). It's about time we align: Meeting deadlines in project teams. (PhD Thesis). Eindhoven: Eindhoven University of Technology.

Giddens, A. (1984). The constitution of society: Outline of a theory of structuration. Cambridge: Policy Press.

Goffman, E. (1962). Asylums : Essays on the social situation of mental patients and other inmates. Chicago: Aldine.

Hofstede, G. (1980). Culture's consequences. London: Sage.

House, R. J., Hanges, P. J., Javidan, M., Dorfman, P., \& Gupta, V. (Eds.). (2004). Culture, leadership, and organizations: The GLOBE study of 62 societies. Thousand Oaks, CA: Sage.

Katz, D., \& Kahn, R. L. (1978). The social psychology of organizations. New York: Wiley. 
Kirchberg, D. M., \& Roe, R. A. (2009). Time management: Performance preferences and multiple goal management strategies. Paper presented at the 14th European Congress of Work \& Organizational Psychology, Santiago de Compostela, Spain.

Lucey, J. J. (2008). Why is the failure rate for organisation change so high? Management Services, 52(4), 10-19.

Lynn, P. (Ed.). (2009). Methodology of longitudinal surveys. Chichester, UK: Wiley.

McGrath, J. E., \& Tschan, F. (2004). Temporal matters in social psychology. Washington, DC: American Psychological Association.

Mitchell, T. R., \& James, L. R. (2001). Building better theory: Time and the specification of when things happen. Academy of Management Review, 26(4), 530-547.

Naus, F. (2007). Organizational cynicism: On the nature, antecedents, and consequences of employee cynicism toward the employing organization. Maastricht Maastricht University (PhD Thesis).

Oprins, E. (2008). Design of a competence-based assessment system for air traffic control training. Maastricht: (PhD Thesis) Universitaire Pers Maastricht.

Raes, A. M. L. (2008). Top mangement team impact on organizations: Determinants from inside and outside the boardroom. Maastricht: (PhD Thesis) Maastricht University.

Raes, A. M. L., Heijltjes, M. G., \& Glunk, U. (2009). Exploring temporal patterns of conflict and trust in teams. In R. A. Roe, M. J. Waller \& S. Clegg (Eds.), Time in organizational research (pp. 127-147). London: Routledge.

Raes, A. M. L., Heijltjes, M. G., Glunk, U., \& Roe, R. A. (2008). The interface of top management team and middle managers: A process model.: Academy of Management Best Paper Proceedings. .

Robbins, S. P. (2007). Organizational behavior. Upper Saddle River, N.J.: Pearson/Prentice Hall. 
Roe, R. A. (1975). Links en rechts in een empirisch perspectief. Amsterdam/ Lisse: Swets \& Zeitlinger.

Roe, R. A. (1981). Martelen: achtergronden van institutionele mishandeling. Paper presented at the Studium Generale RU Limburg, Maastricht, 21 mei, 1981

Roe, R. A. (1994). The transition to a market economy: Implications for employment. . In R. A. Roe \& V. Russinova (Eds.), Psychosocial Aspects of Employment (pp. 3-20). Tilburg/Paris: Tilburg University Press / Paris: Editions Maison des Sciences de l'Homme.

Roe, R. A. (2005). Studying time in organizational behavior. METEOR research memorandum.

Roe, R. A. (2007). The return of the authoritarian personality and work in defense of the civil society. . Paper presented at the European Congress of Psychology, July 3-6, 2007., Prague, Czech Republic.

Roe, R. A. (2008). Time applied psychology: The study of "what happens" rather than "what is". European Psychologist, 13(1), 37-52.

Roe, R. A. (2009). Perspectives on time and the chronometric study of what happens in organizations. In R. A. Roe, M. Waller \& S. Clegg (Eds.), It's about time: Perspectives on time in organizational research (pp. 291-313). Abingdon, UK: Routledge.

Roe, R. A., Solinger, O. N., \& Van Olffen, W. (2009). Shaping organizational commitment. In S. Clegg \& C. L. Cooper (Eds.), The Sage handbook of organizational behaviour (Vol. 2). London: Sage.

Roe, R. A., Waller, M. J., \& Clegg, S. R. (Eds.). (2009). Time in organizational research. London: Routledge.

Roe, R. A., Zinovieva, I. L., Dienes, E., \& Horn, L. A. t. (2001). Firm ownership and work motivation in Bulgaria and Hungary: An empirical study of the transition in the mid-199os. In D. R. Denison (Ed.), Managing organizational change in transition economies (pp. 511-541). Mahwah, NJ: Lawrence Erlbaum Associates Publishers. 
Said, E. W. (1978). Orientalism: Western conceptions of the Orient. New York: Pantheon.

Schnake, M. (1991). Organizational Citizenship: A Review, Proposed Model, and Research Agenda. Human Relations, 44(7), 735-759.

Schwartz, S. H. (1992). Univerals in the content and structure of values: Theoretical advances and empirical tests in 20 countries. In M. Zanna (Ed.), Advances in experimental social psychology (pp. 1-65). New York: Academic Press.

Schwartz, Y. (1992). Travail et usage de soi. In Y. Schwartz (Ed.), Travail et philosophie. Toulouse: Octaris.

Scott, W. R. (2004). Reflections on a halcentury of organizational sociology Annual Review of Sociology, 30, 1-21.

Soeters, J., \& Van Iterson, A. (2002). Blame and praise gossip in organisations: established, outsiders, and the civilising process. In A. Van Iterson, W. Mastenbroek, T. Newton \& D. Smith (Eds.), The civilized organisation: Norbert Elias and the future of organisation studies (pp. 53-71). Amsterdam/Philadelphia: John Benjamins Publishing Company.

Solinger, O., \& Ezerman, C. (2009, 14 maart 2009). Het kleine denken van de hulpverlener. Trouw.

Taylor, F. W. (1911). The principles of scientific management. New York: Harper \& Bros.

Trouillot, M.-R. (2003). Global transformations, Anthropology and the modern world. New York Palgrave Macmillan.

Van de Ven, A. H. (2007). Engaged scholarship: A guide for organizational and social research. Oxford: Oxford University Press.

Van Iterson, A., \& Clegg, S. R. (2008). The politics of gossip and denial in interorganizational relations. Human Relations, 61(8), 1117-1137.

Waller, M. J., Conte, J. M., Gibson, C. B., \& Carpenter, M. A. (2001). The effect of individual perceptions of deadlines on team performance. Academy of Management Review, 26(4), 586-6oo. 
Waller, M. J., Roe, R. A., Gevers, J. M. P., \& Raes, A. M. L. (2005). Team effectiveness in dynamic settings: A bifurcation model. Paper presented at the Workshop 'Human in Command - Military Command Team Effectiveness: Research, Models, and Instruments' Soesterberg, The Netherlands. 30 May - 1 June 2005.

Waller, M. J., Roe, R. A., Gevers, J. M. P., Raes, A. M. L., \& Kaplan, S. A. (2007). Rolling with punches: How control teams manage critical events Paper presented at the Interdisciplinary Network of Group Researchers (INGRoup), Lansing, MI, July 12-14, 2007.

Waller, M. J., \& Uitdewilligen, S. (2009). Talking to the room: Collective sensemaking suring crisis situations. In R. A. Roe, M. J. Waller \& S. R. Clegg (Eds.), Time in organizational research (pp. 186-203). London: Routledge.

Weick, K. E. (1979). The social psychology of organizing. New York: McGraw-Hill.

Weick, K. E. (1995). Sense making in organizations. London: Sage.

Wolf, E. (1982). Europe and the people without history. Berkeley: University of California Press. 
